Ending Book Hunger 
This page intentionally left blank 

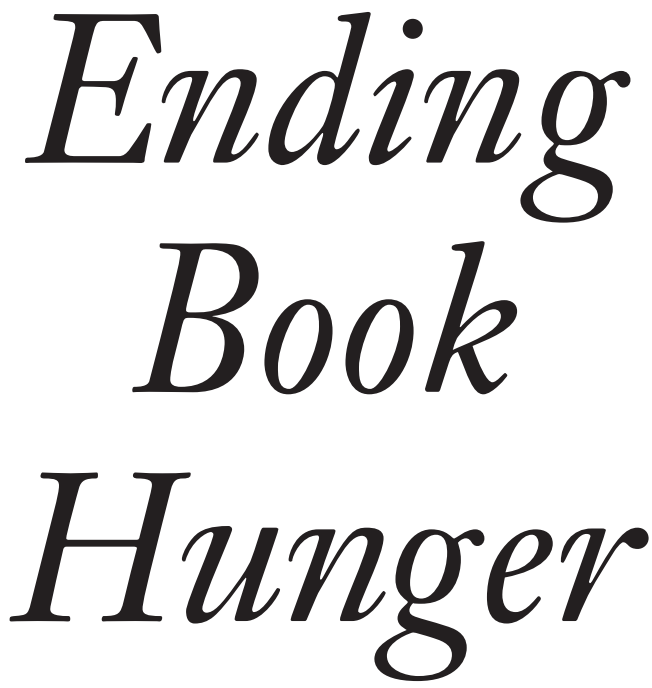

Access to Print Across

Barriers of

Class and Culture

\section{Lea Shaver}

Yale UNIVERSITY PRESS

New Haven \& London 
Published with assistance from the foundation established in memory of Amasa Stone Mather of the Class of 1907, Yale College.

\section{Copyright () 2019 by Lea Shaver.}

The author has made a digital version of this book available at no charge at http://www.bookhunger.org.

This book is licensed for public use under the terms of the Creative Commons Attribution-NonCommercial-ShareAlike 4.0 International License (CC BY-NC-SA 4.0). Under its terms, you are free to make and share a copy, translation, recording, or excerpt of this book for personal, educational, charitable, or other noncommercial purposes. For complete terms, visit https://creativecommons.org/licenses/by-nc-sa/4.o/.

This book may not be reproduced for commercial advantage, in whole or in part, including illustrations, in any form (beyond that copying permitted by Sections I07 and Io8 of the U.S. Copyright Law and except by reviewers for the public press), without written permission from the publishers.

Yale University Press books may be purchased in quantity for educational, business, or promotional use. For information, please e-mail sales.press@yale.edu (U.S. office) or sales@yaleup.co.uk (U.K. office).

Set in Janson type by IDS Infotech Ltd.

Printed in the United States of America.

ISBN 978-0-300-22600-3 (hardcover : alk. paper)

Library of Congress Control Number: 2019941035

A catalogue record for this book is available from the British Library.

This paper meets the requirements of ANSI/NISO Z39.48-1992

(Permanence of Paper). 